\title{
Structural Characteristics of Drug Intercalated Hydrotalcites Used in Dental Medicine
}

\author{
GEORGETA ZEGAN ${ }^{1}$, EDUARD RADU CERNEI ${ }^{1}$, ELENA MIHAELA CARAUSU², LOREDANA GOLOVCENCU ${ }^{1 *}$, \\ DANIELA ANISTOROAEI ${ }^{1}$ \\ ${ }^{1}$ Grigore T. Popa University of Medicine and Pharmacy, Faculty of Dental Medicine, Department of Surgery, 16 University Str., \\ 700115, Iasi, Romania \\ ${ }^{2}$ Grigore T. Popa University of Medicine and Pharmacy, Faculty of Dental Medicine, Department of Management and Public \\ Health, 16 University Str., 700115, Iasi, Romania
}

\begin{abstract}
Metronidazole active molecules were intercalated in the inner space of MgAl layered double hydroxides by simple coprecipitation method. The new synthesized nanohybrid material and the pristine hydrotalcite were characterized by different techniques such as X-ray diffraction, infrared spectroscopy and UV-vis spectroscopy verifying thus the incorporation of the antibiotic into the lamellar gallery of hydrotalcite type anionic clay. Studies regarding metronidazole controlled release from synthetic nanocomposite showed that the organic-inorganic nanohybrid structure can serve as drug controlled release system for a wide variety of antibiotics and other molecules used in dental medicine in order to maintain good public health dentistry.
\end{abstract}

Keywords: drug intercalated hydrotalcites, structural characteristics, antibacterial properties, public health dentistry, orthodontics.

In lastfew years, nanotechnology has gained an increase attention due to the different area of applications. Nanomedicine field uses nanomaterials as drug delivery carriers for treatment of many diseases [1].

Layered double hydroxides (LDHs) or hydrotalcitesare a class of anionic clays having positive charged lamella counterbalanced by interlayer anions and water molecules [2]. General chemical formula of LDHs is expressed as

$$
M_{1-x}^{(I I)} M_{x}^{(I I I)}(\mathrm{OH})_{2}\left(\mathrm{~A}^{\mathrm{n}}\right)_{\mathrm{x} / \mathrm{n}} \times \mathrm{yH}_{2} \mathrm{O}
$$

where, $\mathrm{M}^{(\mathrm{II})}$ represents divalent cation, $\mathrm{M}^{\text {(III) }}$ trivalentcation, $A$ is interlayer anion, $n$-charge of inter layer ion, and $x$ and $y$ are fraction constants.

Intercalation of various molecules into layered structure of hydrotalcites offers new opportunities for developing nanohybrids that possess desired functionality. Many negatively charged biomolecules can be incorporated between layers as charge compensating anions by ion exchange route or coprecipitation [3, 4]. Novel hybrids type LDHs-drugs are well designed on nanometer scale to act as drug delivery systems. Therefore, hydrotalcites can act as inorganic vectors for different organic molecules like active principles that are negatively charged and intercalated into LDHs gallery. Thus, the novel formulations gainincreased stabilization energy due to their electrostatic interactions [5-9]. The as formed nanostructures can be obtained by coprecipitation method, reconstruction and anion exchange path $[10,11]$.

A number of guestmolecules such as anti-inflammatory, cardiovascular or antiinfectious agents could be intercalated between LDHs sheets to control the release and pharmacokinetic profile by replacing metal ions in layers of host hydrotalcite. Choosing metal layers, pH stability and antacid performance became controllable by restricting molecular interactions that should enhance longterm stability. Interlayer region of drug-hydrotalcite matrix can be regarded as a micro-vessel in which active molecules may be stored and then released by a de intercalation action in a medium containing other anions.
That depends on their diffusion through particle in controlling drug release rapidity [12-14]. A lot of drugs have been successfully incorporated in layered double hydroxides including antibiotics, antiinflamatories and chemotherapeutic agents among others [15].

For many years, antibiotics are one of the most important pharmaceuticals used in medicine to prevent and treat bacterial infections. Doxycycline is used extensively to treat periodontal diseases but is preferable to use metronidazole (fig. 1) because of the bacterial resistence knowing that this drug is a selective agent against anaerobic bacteria.<smiles>O=[N+]([O-])c1cnc2n1CCCC2</smiles>

Fig.1. Metronidazole- chemical structure

Orthodontics specialists agree that the therapeutic goal to stop tooth loss is the limiting of bacteria multiplication responsible for periodontal diseases by mechanical cleaning action and topical application of antimicrobial agents [16-19].The major purpose of this work was to synthesize and characterize the initial nanostructure of $\mathrm{MgAl} /$ hydrotalcite and the Metronidazole-MgAl/ hydrotalcitenanohybrid to further use it in treatment of oral diseases.

\section{Experimental part}

Materials and methods

$\mathrm{MgAl} /$ hydrotalcite synthesis was achieved by using coprecipitation method.

A solution containing $\mathrm{Mg}\left(\mathrm{NO}_{3}\right)_{2} \cdot 6 \mathrm{H}_{2} \mathrm{O}$ and $\mathrm{Al}\left(\mathrm{NO}_{3}\right)_{3} \cdot 9 \mathrm{H}_{2} \mathrm{O}$ in a molar ratio of 3:1 dissolved in $100 \mathrm{mlLdeionized} \mathrm{water}$ and a solution containing $\mathrm{NaOH} / \mathrm{Na}_{2} \mathrm{CO}_{3}$ were added drop wise until complete precipitation at $p \mathrm{H} 9$. The obtained precipitate suspension was vigorously stirred for $24 \mathrm{~h}$ at 
$65^{\circ} \mathrm{C}$, filtered, washed with deionized water and dried at $40^{\circ} \mathrm{C}$.

Metronidazole-MgAl/hydrotalcite was synthesized using the same procedure by adding antibiotic to the medium before precipitation in a molar ratio of 2/3/1 Metronidazole/ $\mathrm{Mg}$ salt/Al salt. The final suspension was vigorously stirred at $60^{\circ} \mathrm{C}$ for $24 \mathrm{~h}$, filtered, washed with distilled water and dried at $40^{\circ} \mathrm{C}$.

Structural characteristics of MgAl/hydrotalcite and Metronidazole-MgAl/hydrotalcite were determined using XRD and FTIR techniques.

\section{Results and discussions}

FTIR analysis and XRD patterns confirmed structural properties of MgAl/hydrotalcite and Metronidazole-MgAl/ hydrotalcite nanoparticles.

Figure 2 presents FTIR spectra of raw MgAl/hydrotalcite before and after metronidazole incorporation. An intense and broad peak at around $3450 \mathrm{~cm}^{-1}$ may be attributed to the stretching vibration of the $-\mathrm{OH}$ groups from hydroxide layers and interlayer water respectively. The band at approximately $1660 \mathrm{~cm}^{-1}$ is attributed to bending vibration of the water molecules. At around $1380 \mathrm{~cm}^{-1}$ it can be observed a strong absorption band attributed to nitrate anions. The bands under $1000 \mathrm{~cm}^{-1}$ correspond to M-O stretching and $\mathrm{M}-\mathrm{OH}$ bending vibration in the hydrotalcite layer.

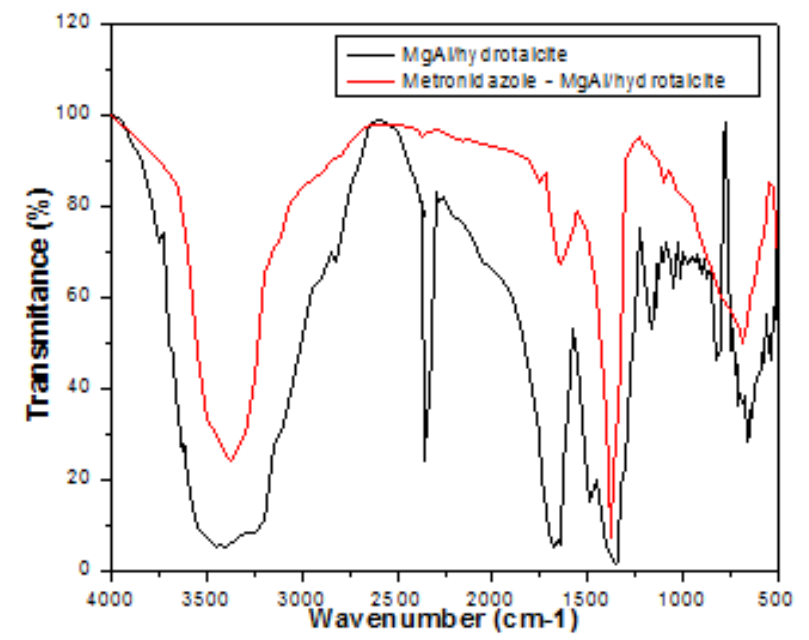

Fig. 2. FTIR spectra of MgAl/hydrotalcite and Metronidazole-MgAl/ hydrotalcite

Some peaks exhibited changes after intercalation of metronidazole in the brucite layer. Several peaks disappeared while others shifted to new values which confirmed the binding of antibiotic molecules to the hydrotalcite layers.

XRD pattern of MgAl/hydrotalcite before and after metronidazole intercalation in layered structure is presented in figure 3 . It is noticeable that XRD features of $\mathrm{MgAl} /$ hydrotalcite before antibiotic inclusion in brucite structure shows sharp and symmetrical peaks and few high-angle asymmetrical peaks, proving the formation of MgAl/hydrotalcite crystalline structure.

A reflection peak at $2 \theta=10.00^{\circ}$ corresponding to (003) reveals the initial MgAl- $\mathrm{NO}_{3}$ phase and the other peaks at $2 \theta=20.00^{\circ}, 34.66^{\circ}, 38.34^{\circ}$ and $44.4^{\circ}$ associated to (006), (009), (012) and (018) are specific to hydrotalcite nanostructure. Moreover, the sharp peak at $2 \theta=28.16^{\circ}$ resulted from magnesium oxide formation. The small peak at $2 \theta=60.48^{\circ}$ corresponds to ions distribution along the surface of host layer.

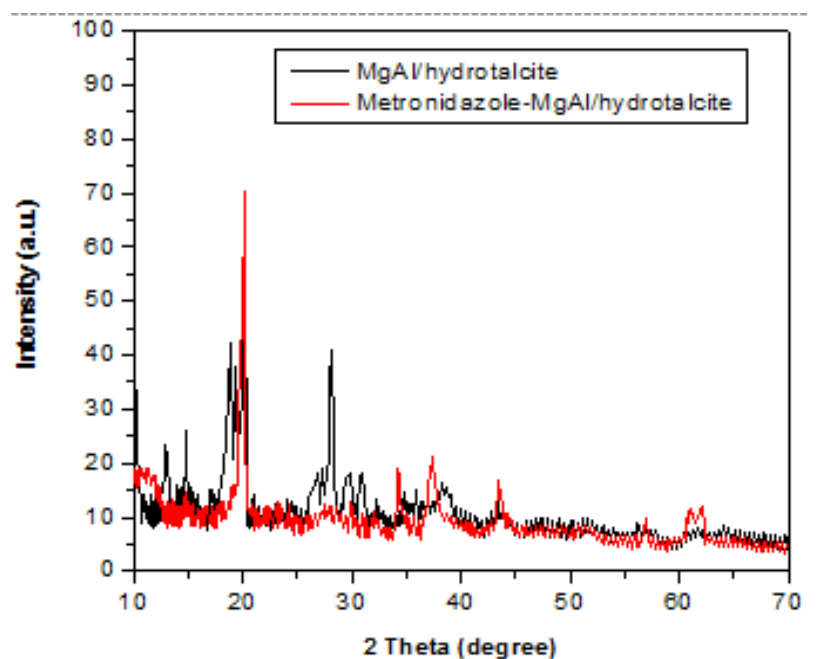

Fig. 3. XRD pattern of MgAl/hydrotalcite and Metronidazole-MgAl/ hydrotalcite

For nanohybrid structure, it can be observed that the peaks at $2 \theta=10.00^{\circ}, 20.00^{\circ}, 34.66^{\circ}, 38.34^{\circ}, 44.4^{\circ}$ and $60.48^{\circ}$ remained unchanged after metronidazole intercalation, suggesting that the structure of hydrotalcite did not modified after the inclusion of antibiotic in the layered structure. The peak observed at $2 \theta=10.48^{\circ}$ shifted to stronger angle after metronidazole insertion implying a decrease of MgAl/hydrotalcite interlayer distance.

The intercalation of metronidazole into the hydrotalcite layers is reversible meaning that when the nanocomposite is suspended in a proper medium the drug is released.

Figure 4 reveals that the release occurred in the presence of exchangeable anions with the hosted antibiotic by suspending the nanohybrid in an aqueous solution containing $0.2 \mathrm{M} \mathrm{NaCl}$.

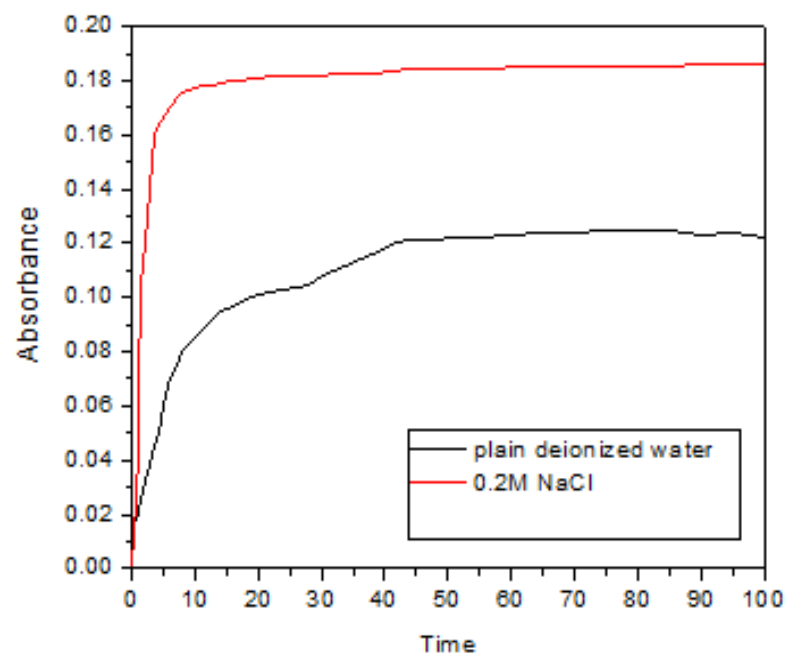

Fig. 4. Release profile of antibiotic from Metronidazole-MgAl/ hydrotalcite nanohybrid

A significant release is observed when the nanohybrid is suspended in plain deionized water buffered at $\mathrm{pH} 7$. Probably a small amount of $\mathrm{Cl}^{-}$along with $\mathrm{HCO}_{3}{ }^{-}$coming from the atmospheric $\mathrm{CO}_{2}$ are capable to exchange some of the drug.

\section{Conclusions}

Nanomedicine could be the prior field to use nanotechnology since living matter is mostly composed of biological nanostructures. Hybridization of drug with LDHs type nanomaterials results in remarkable efficiency and stability thus improving oral health. Anionic clays may be considered nanodevices that enhance antibiotic 
bioavailability and allows drug controlled release and fewer adverse effects respectively. The new MetronidazoleMgAlhydrotalcitenanocomposite formula permits a good drug local sustained release in oral cavity. These results provide the implementation of antibiotic therapeutic concentration in the action site and reductions of drug side effects while ensure the patient's oral health.

\section{References}

1.AMBROGI V., FARDELLA G., GRANDOLINI G., NOCHETTI M., J ournal of Pharmaceutical Sciences, 92, 2003, p. 1407.

2.CALABRESE I., CAVALLARO G., SCIALABBA C., LICCIARDI M., MERLI M., SCIASCIA L., TURCOLIVERI M., International J of Pharmaceutics, 457, 2013, p. 224.

3.SUNG-HO H., YANG-SU H., CHOY J.H., Bull Korean Chem Soc, 22 2001, p. 1019.

4.KHAN A.I., LEI L., NORQUIST A.J, O'HARE D., Chem Commun, 22, 2001, p. 2342.

5.CHOY J.H., KWAK S.Y., J EONG Y.J, PARK J.S, Angew Chem (Int Ed), 39, 2000, p. 4042.

6.TANTARU, G., MARIN, L., VIERIU, M., PANAINTE, A.D., POIATA, A., APOSTU, M., BIBIRE, N., Rev Chim (Bucharest), 66, no. 12, 2015, p. 1965.
7.CALIN, A.M., DEBITA, M., DRAGOMIR, R., STEFANESCU, O.M., BUDACU, C., SZALONTAY, A.S., Rev Chim (Bucharest), 68, no. 11, 2017, p. 2618.

8. TANTARU, G., APOSTU, M., Rev Chim (Bucharest), 61, no. 7, 2010, p. 632.

9.CRETEANU, A., OCHIUZ, L., VASILE, C., VIERIU, M., TANTARU, G., Farmacia, 65, no. 4, 2017, p. 545.

10.W ONG F., BUCHHEIT R.G, Progr Organic Coatings, 51, 2004, p. 91. 11.JUNG W.C., HUH Y.D, Bull Korean ChemSoc, 17, 1996, p. 547.

12.WEI M., SHI S., WANG J., LI Y., DUAN X., J Solid State Chem, 177, 2004, p. 2534.

13.CHOY J.H, KWAK S.Y, PARK J .S, J EONG Y.J , J MaterChem, 11, 2001, p. 1671.

14.AMBROGI V., FARDELLA G., GRANDOLINI G., NOCCHETTI M., PERIOLI L., J Pharm Sci, 92, 2003, p. 1407.

15.YANG J .H., LEE, J.H., RYU H.J ., A.ELZATAHRYB A., ALOTHMAN Z.A., CHOY, J.H., 130, 2016, p. 20.

16.NOYAN U., YILMAZ S., KADIR B., ACAR O., BUGET E., J. Clin. Periodontol, 24 1997, p. 158.

17.BECKER W., BERG L., BECKER S.E., J. Periodontol., 50, 1979, p. 234.

18.LINDHE J., HHAFFAJEE A.J ., SOCRANSKY S., J. Clin. Periodontol., 10, 1983, p. 433.

19. LISTGARTEN M.A., J. Periodontol. Res., 22, 1987, p. 172.

$\overline{\text { Manuscript received: } 5.11 .2018}$ 